\title{
Samband tryggðar og ánægju viðskiptavina með pjónustu á fyrirtækjamarkaði
}

\author{
Auður Hermannsdóttir og Svanhildur Ásta Kristjánsdóttir
}

\begin{abstract}
Ágrip
Rannsóknir hafa sýnt fram á jákvætt samband tryggðar viðskiptavina og árangurs fyrirtækja á mörgum sviðum. Рað ætti pví að vera markmið stjórnenda að auka tryggð viðskiptavina eða fjölda peirra sem eru tryggir fyrirtækinu. Vitað er аð forsenda pess að viðskiptavinur geti verið tryggur er að hann sé ánægður með fyrirtækið og pjónustu pess og eftir atvikum vörur. Sambandið á milli ánægju viðskiptavina og tryggðar hefur töluvert verið rannsakað á einstaklingsmarkaði en mun færri rannsóknir hafa verið gerðar á viðfangsefninu á fyrirtækjamarkaði. Markmið rannsóknarinnar var að kanna hversu sterk tengsl eru á milli ánægju viðskiptavina með pjónustu og tryggðar á markaði fyrir prentpjónustu. Rannsóknareiningin var rótgróið íslenskt fyrirtæki sem hefur fjölbreyttan viðskiptavinahóp. Rafrænn spurningalisti var sendur á viðskiptavini fyrirtækisins par sem ánægja peirra með pjónustuna og tryggð var mæld. Niðurstöðurnar sýndu að tengsl ánægju og tryggðar voru jákvæð, en veik. Jákvæð veik tengsl reyndust vera á milli ánægju og ætlaðra endurkaupa, mjög veik neikvæð tengls milli ánægju og neikvæðs umtals og miðlungs sterk jákvæð tengsl á milli ánægju og meðmæla með fyrirtækinu. Niðurstöðurnar benda til pess að ekki sé munur á verðteygni eftir pví hvort viðskiptavinir eru ánægðir eða óánægðir með pjónustuna. Rannsóknin gefur tilefni til að ætla að ef stjórnendur á prentmarkaði hyggjast ná fram tryggð og peim ávinningi sem hún getur skilað fyrirtækjum, pá purfi að tryggja mikla ánægju viðskiptavina með pjónustugæðin.
\end{abstract}

\begin{abstract}
Research has shown a positive correlation between customers' loyalty and business success in various fields. Customer loyalty is of concern to managers and because of the influence that loyalty has it should be managers' mission to increase the number of loyal customers. But it can be difficult to realize how to increase loyalty of individual customer and thereby increase the number of loyal customers. It is known that customer's satisfaction is prerequisite to customer's loyalty, and the relationship between satisfaction and loyalty has been studied thoroughly in B2C, but much less is know about this relationship on the $\mathrm{B} 2 \mathrm{~B}$ market. The purpose of the research was to study the strength of the corrolation between customers' satisfaction and customers' loyalty in the B2B market for printing service. The research subject was an established Icelandic company with a broad range of customers. A questionnaire was sent to the company's customers over the Internet where their satisfaction and loyalty was measured. The findings show that the corrolation between satisfaction and loyalty is positive, but week. Week positive correlation was also found between satisfaction and repurchase intentions, very week negative correlation between
\end{abstract}


satisfaction and negative word of mouth and average positive correlation between satisfaction and WOM referrals. The findings give reson to belive that in the market for printing service the price elasticity of demand does not vary between satisfied and unsatisfied customers. According to the findings, managers who intend to reach loyalty among their customers and the benefits gained from loyalty, should emphasis great satisfaction of customers with the service quality.

JEL-flokkun: $x x x x$

Lykilhugtök: Tryggð viðskiptavina, ánægja viðkiptavina, fyrirtækjamarkaður, B2B 


\section{Inngangur}

Grundvallar forsenda pess að fyrirtæki séu lífvænleg er að til staðar séu viðskiptavinir. Viðskiptavinirnir eru lífæð fyrirtækja og pá parf að meðhöndla sem slíka. Til að auka líkur á stöðugu innstreymi tekna er ákjósanlegt að skapa sterkan hóp tryggra viðskiptavina sem eiga í endurteknum viðskiptum við fyrirtæki. Síendurtekin viðskipti tryggra viðskiptavina eru talin sérlega mikilvæg á fyrirtækjamarkaði (business to business) (Rauyruen, Miller og Groth, 2009) og eðli pess sambands sem er á milli fyrirtækja sem eiga í viðskiptum sín á milli (Caceres og Paparoidamis, 2007; Cugini, Carú og Zerbini, 2010). Fyrirtækjamarkaður kann að lúta öðrum lögmálum en einstaklingsmarkaður (business to consumer), enda er pað vel pekkt að kaupákvörðun á slíkum markaði er að mörgu leiti flóknari en á einstaklingsmarkaði. Á fyrirtækjamarkaði eru viðskiptavinir oft kröfuharðir og ætlast gjarnan til að fá góða umbun fyrir endurtekin viðskipti, t.d. í formi lægra verðs (Reinartz og Kumar, 2002). Traust hefur verið álitinn mikilvægur páttur pegar kemur að tryggð (Chadhuri og Holbrook, 2001; Gounaris, 2005; Ranaweera og Prabhu, 2003; Rauyruen o.fl., 2009) en í viðskiptum á fyrirtækjamarkaði er traust á milli aðila sérlega mikilvægt. Báðir aðilar verða að treysta hvorum öðrum til að vera tilbúnir til að halda viðskiptasambandinu áfram (Ranaweera og Prabhu, 2003 Rauyruen o.fl., 2009). Sé gott traust til staðar getur pað einnig dregið úr kostnaði, t.d. við samningagerð (Bendapudi og Berry, 1997). Раð að ná inn nýjum viðskiptum á pessum markaði er almennt álitið upphafsskref í að byggja upp og viðhalda langtíma sambandi með pað аð markmiði að síendurtekin viðskipti eigi sér stað. Баð er pví áhersluatriði að átta sig á hvað stuðlar að pví að viðskiptavinir haldi áfram að vilja vera í viðskiptasambandinu (Gounaris, 2005).

Forsenda pess að tryggð geti myndast er að viðskiptavinir séu ánægðir með fyrirtækið og frammistöðu pess (Anderson, Fornell og Lehmann, 1994; Oliver, 1999). Með pví að stuðla að ánægju viðskiptavina t.d. með framúrskarandi pjónustu aukast par af leiðandi líkur á tryggð (Curasi og Kennedy, 2002). Í gegnum tíðina hafa flestar rannsóknir á sambandi ánægju og tryggðar verið á einstaklingsmarkaði. Mun færri hafa snúið að fyrirtækjamarkaði (Davis-Sramek, Droge, Menzer og Myers, 2009; Pick, 2010; Russell-Bennett, McColl-Kennedy og Coote, 2007), en á síðastliðnum áratug hefur slíkum rannsóknum pó fjölgað. Algengt er að í rannsóknum sé aðeins einblínt á einn markað og oft aðeins á eitt fyrirtæki. Meðal fyrirtækjamarkaða sem hafa verið til skoðunar eru hugbúnaðarpjónusta (Taylor og Hunter, 2003), ferðapjónusta (Lam, Shankar, Erramilli og Murphy, 2004), vöruflutningamarkaður (Molinari, Abratt og Dion, 2008), auglýsingagerð (Caceres og Paparoidamis, 2007; Cugini o.fl., 2010) og stáliðnaður (Liao, 2012).

Markmið rannsóknarinnar er að kanna hversu sterk tengsl eru á milli ánægju viðskiptavina með pjónustu og tryggðar á fyrirtækjamarkaði fyrir prentpjónustu. Könnuð verða tengsl milli ánægju með pjónustu annars vegar og meðmæla með fyrirtækinu, neikvæðs umtals, endurkaupa og verðteygni hins vegar. Rannsóknareiningin er íslenskt fyrirtæki (hér eftir kallað Fyrirtækið) sem starfar í prentpjónustu bæði á fyrirtækjamarkaði og á einstaklingsmarkaði. Hér er til skoðunar sá hluti fyrirtækisins sem snýr að fyrirtækjamarkaði.

Fáar greinar hafa birtst um tryggð viðskiptavina á íslenskum markaði (Friðrik 
Eysteinsson og Pórhallur Guðlaugsson, 2010; Pórhallur Guðlaugsson, 2010) og eftir bestu vitund höfunda hefur engin rannsókn verið gerð á tengslum ánægju með pjónustu og tryggðar á fyrirtækjamarkaði hér á landi. Auk pess hafa höfundar ekki fundið erlendar greinar par sem horft er til pessa viðfangsefnis á markaði með prentpjónustu. Rannsóknarspurningin er: Hversu sterk tengsl eru á milli ánægju með pjónustu og tryggðar viðskiptavina í prentpjónustu? Mikilvægt er að hafa í huga að hér er umrætt samband aðeins skoðað hjá einu fyrirtæki. Niðurstöðurnar ber að skoða í pví ljósi og varast að draga of sterkar ályktanir og alhæfa yfir á önnur fyrirtæki. Höfundar líta svo á að hér sé um að ræða fyrstu rannsókn af mörgum á pessu viðfangsefni á fyrirtækjamarkaði hér á landi. Nauðsynlegt og áhugavert er að framkvæma sambærilega rannsókn á fleiri fyrirtækum á fyrirtækjamarkaði og ná með pví meiri skilningi á sambandinu milli ánægju viðskiptavina og tryggðar á slíkum markaði.

Hér á eftir verður hugtakið tryggð skilgreint, greint frá mismunandi stigum tryggðar og fjallað um mögulegan ávinning. Pví næst verður fjallað um skilgreiningar á ánægju viðskiptavina og í kjölfarið samband ánægju og tryggðar. Pví næst verður fjallað um pá aðferðafræði sem beitt var við rannsóknina, farið yfir niðurstöður og að lokum er umræða um pýðingu niðurstaðnanna og pær settar í samhengi við fyrri rannsóknir á viðfangsefninu.

\section{Tryggð viðskiptavina skilgreind}

Tryggð viðskiptavina byggir á sambandi sem er viðvarandi yfir tíma og viðskiptavinurinn velur meðvitað að eiga viðskipti við tiltekið fyrirtæki umfram önnur, p.e.a.s. viðskiptin eru ekki háð tilviljun (Söderlund, 2006). Tryggð felur jafnframt í sér ákveðna fjárfestingu eða jafnvel fórn af hálfu viðskiptavinarins til að styrkja sambandið við fyrirtækið. Í pví gæti t.d. falist að viðskiptavinurinn haldi áfram tryggu sambandi við fyrirtæki vegna gæða eða langtíma vænts ávinnings, prátt fyrir að fyrirtækið bjóði ekki lægsta verðið á markaðnum (Bowen og Shoemaker, 1998; Reichheld, 2003). Til að teljast raunverulega tryggur viðskiptavinur verður viðkomandi pví að hafa áform um að halda viðskiptunum áfram (McMullan, 2005). Odin, Odin og Valette-Florance (2001) skilgreina viðskiptavini sem trygga sem hafa tilhneigingu til að kaupa aftur og aftur sama vörumerkið (eða frá sama fyrirtæki) og telja að vörumerkið (fyrirtækið) sjálft sé veigamikill páttur í valinu. Bowen og Chen (2001) skilgreindu trygga viðskiptavini sem viðskiptavini sem hafa jákvætt viðhorf gagnvart fyrirtækinu, eru skuldbundnir pví að halda áfram viðskiptum við fyrirtækið og mæla með fyrirtækinu við aðra.

Áður fyrr var fyrst og fremst litið svo á að tryggð viðskiptavina endurspeglaðist í hegðun peirra og áformum um hegðun, t.d. tíðni viðskipta og hvort fólk hefði í hyggju að halda viðskiptum áfram og voru mælingar á tryggð pví byggðar á pví (Baumann, Burton og Elliot, 2005; Oliver, 1999; Rundle-Thiele og Mackey, 2001; Zeithaml, Berry og Parasuraman, 1996). Í dag er hins vegar almennt viðurkennt að tryggð snúist um mun meira en bara endurtekin viðskipti. Stundi viðskiptavinur síendurtekin viðskipti við fyrirtæki getur pað verið vegna annarra ástæðna en raunverulegrar tryggðar. Рað gæti t.d. verið vegna pess að fáir valkostir 
eru í boði á markaðnum eða vegna útgönguhamla úr viðskiptasambandinu (Odin o.fl., 2001; Reichheld, 2003). Ástæðan gæti einnig verið ákveðinn dofi (inertia) par sem viðskiptavinurinn verslar við tiltekinn aðila eða tiltekið vörumerki af vana án pess að skynja raunverulegan mun á milli fyrirtækja/vörumerkja (Hellier, Geursen, Carr og Rickard, 2003; Odin o.fl., 2001). Mikilvægt er að viðskiptavinurinn skynji ákveðinn mun á milli fyrirtækja/vörumerkja til að um tryggð sé að ræða, en ekki vegna einhvers konar dofa. Sú nálgun að líta á tryggð eingöngu út frá hegðun gefur pví í skyn að pað sé afar erfitt fyrir fyrirtæki að hafa áhrif á endurtekna kauphegðun, par sem fyrirtækið hefur engar upplýsingar um hver hin raunverulega ástæða tryggðarinnar er (Odin o.fl., 2001). Að nota hegðun eingöngu sem mælikvarða á tryggð skýrir pví ekki nægilega vel hvernig og hvers vegna tryggð myndast og/eða próast (Dick og Basu, 1994; Hellier o.fl., 2003). Til að skilja tryggð viðskiptavina heildrænt er pví nauðsynlegt að taka bæði tillit til hegðunar og hugrænna pátta (Back og Parks, 2003; Day, 1969; Dick og Basu, 1994; Oliver, 1999).

Í dag eru flestir fræðimenn sammála um að tryggð viðskiptavina samanstandi af tveimur víddum; annars vegar hegðunarvídd (loyalty as behavior) og hins vegar hugrænni vídd (loyalty as a mental state) (Bowen og Chen, 2001; Odin o.fl., 2001; McMullan, 2005; Russell-Bennett o.fl., 2007; Söderlund, 2006). Margir hafa kosið að kalla síðarnefndu víddina viðhorfsvídd (loyalty as attitude) en að mati Söderlund (2006) er heppilegra að tala um hugræna vídd. Ástæðan er sú að víddin tekur á fleiri páttum sem gerast í hugum viðskiptavina en viðhorfi.

Hegðunarvíddin endurspeglast í beinni hegðun viðskiptavina gagnvart fyrirtækinu, t.d. tíðni viðskipta, lengd viðskiptasambands, hlutdeild í kaupum (share of wallet) og umtali um fyrirtækið við aðra (Baumann o.fl., 2005; Mellens, Dekimpe og Steenkamp, 1996). Nauðsynlegt er að taka tillit til hegðunar við mælingar á tryggð, en eins og rakið hefur verið, er pað ekki nægjanlegt. Mikilvægt er að taka einnig tillit til hugrænna pátta, enda hafa undirliggjandi viðhorf neytenda áhrif á kaupferli og mat við kaup (Mellen, Dekimpe og Steenkampe, 1996). Hugræna víddin endurspeglast t.d. í pví viðhorfi sem viðskiptavinurinn hefur gagnvart fyrirtækinu, hvort hann beri hlýhug til fyrirtækisins og/eða starfsmanna pess, hvort hann finni fyrir tengslum eins og skuldbindingu og trausti gagnvart fyrirtækinu, hvort hann velji fyrirtækið markvisst fram yfir önnur fyrirtæki og áformum um áframhaldandi viðskipti (Baumann o.fl., 2005; Mellens o.fl., 1996). Með pví að nota viðhorf sem mælikvarða á tryggð er lögð áhersla á mikilvægi pess að skilja undanfara kaupanna eins og t.d. af hverju eitt fyrirtæki/vörumerki er valið umfram annað (preference) (Ajzen og Fishbein, 1980; Mellen o.fl., 1996), skuldbindingu (Traylor 1981; Foxall 1987; Martin og Goodell 1991; Mellens o.fl., 1996) og ásetning um (endur)kaup (Ajzen og Fishbein 1980; Oliver 1980; Westbrook og Oliver 1981; Patterson, Johnson og Spreng, 1997). Hegðunarvíddin ræðst að hluta til af aðstæðubundnum páttum, eins og t.d. aðgengileika tiltekinnar pjónustu eða vara, en hugræna víddin er meira viðvarandi og síður háð aðstæðum hverju sinni (Caceres og Paparoidamis, 2007).

Niðurstöður Russell-Bennett o.fl. (2007) sýndu að jákvæð tengsl eru á milli hugrænnar tryggðar og hegðunartryggðar. Niðurstöðurnar bentu jafnframt til pess að hátt stig hugrænnar tryggðar væri forsenda mikillar hegðunartryggðar. Pað er pví líklegt að neytendur sem sýna mikla hugræna tryggð gagnvart fyrirtæki sýni jafnframt mikla hegðunartryggð. Petta samræmist umfjöllun Caceres og Paparoidamis (2007) sem benda á að pað eru hugrænu pættirnir sem drífa áfram 
hegðun. Niðurstöður Russell-Bennett o.fl. (2007) benda til pess að hugsanlega nægi að mæla hugræna tryggð og ganga út frá að niðurstöðurnar gefi jafnframt vísbendingar um hegðunartryggð.

Prátt fyrir að fræðimenn séu almennt sammála um nauðsyn pess að leggja bæði mat á hegðunarvídd og hugræna vídd, hafa aðferðir við mælingar verið ólíkar, bæði hvað varðar fjölda tryggðarbreyta sem eru til skoðunar og hvaða breytur falla undir hvora vídd.

\section{Mismunandi gerðir tryggðar}

Viðskiptavinir fyrirtækja eru ekki annað hvort tryggir eða ekki tryggir, heldur eru peir á mismunandi stigum tryggðar. Fjallað hefur verið um mismunandi flokka tryggðar í ýmsum rannsóknum (sjá t.d. Dick og Basu, 1994; Jones og Sasser Jr., 1995; Pritchard og Howard, 1997). Í flokkun Gremler og Brown (1998) er sérstaklega horft til pjónustufyrirtækja. Peir bentu á að vegna einkenna pjónustu, sem aðgreinir hana frá ápreifanlegum vörum, geti tryggð gagnvart pjónustufyrirtækjum verið byggð á pjónustutengdum páttum, sem ekki eiga við pegar um ápreifanlegar vörur er að ræða. Peir skiptu tryggð gagnvart pjónustufyrirtækjum pví annars vegar í tryggð byggða á ópersónulegum tengslum (impersonal bonds) og hins vegar tryggð byggða á félagslegum tengslum (interpersonal bonds).

Tryggð byggð á ópersónulegum tengslum getur einkennst af pví að viðskiptavinurinn metur skiptikostnað of háan til að fara úr viðskiptasambandinu. Slík tryggð getur einnig byggst á pví að viðskiptavinurinn fái einhvers konar umbun fyrir viðskiptin sem heldur honum í sambandinu.

Tryggð byggð á félagslegum tengslum einkennist af peirri upplifun viðskiptavinarins að um persónulegt og félagslegt samband sé að ræða milli hans og starfsfólks pjónustufyrirtækisins. Viðskiptavinurinn lítur á tengslin sem vinaleg, notaleg og byggð á trausti. Gremler og Brown (1998) töldu að ef mynda ætti raunverulega tryggð hjá viðskiptavinum væri tryggð byggð á félagslegum tengslum afar mikilvæg.

Flokkun Curasi og Kennedy (2002) er líklega sú ítarlegasta. Cursai og Kennedy (2002) skiptu viðskiptavinum niður á fimm tryggðarstig eftir (a) peim tengslum sem samband viðskiptavinanna við fyrirtækið byggir á, (b) pví hlutverki sem ánægja peirra gagnvart fyrirtækinu gegni, (c) hversu mikla skuldbindingu viðskiptavinurinn leggur í samband sitt við fyrirtækið og (d) hversu mikið val viðskiptavinurinn hefur í raun og veru til að skipta um fyrirtæki. Í töflu 1 má sjá pessa flokkun viðskiptavina.

Fáskiptinni trygglyndi og punktatrygglyndi svipar nokkuð til tryggðar sem byggir á ópersónulegum tengslum samkvæmt flokkun Gremler og Brown (1998), en ánægjutrygglyndi og postulum svipar að hluta til tryggðar sem byggir á félagslegum tengslum í flokkun peirra félaga. 
Tafla 1. Mismunandi stig tryggðar eftir flokkun Curasi og Kennedy

\begin{tabular}{ll}
\hline Tryggðarstig & Lýsing \\
\hline Fangar (prisoners) & $\begin{array}{l}\text { Hafa fáa valkosti. Geta verið gríðarlega óánægðir en halda pó } \\
\text { áfram viðskiptum. Finnst peir oft fastir. }\end{array}$ \\
$\begin{array}{l}\text { Fáskiptin trygglyndi } \\
\text { (detached loyalists) }\end{array}$ & $\begin{array}{l}\text { Hafa valkosti, en telja skiptikostnaðinn of háan. Sambandið } \\
\text { byggir á hentugleika, myndu líklega fara annað ef pað myndi } \\
\text { henta betur. }\end{array}$ \\
$\begin{array}{l}\text { „Punkta“-trygglyndi } \\
\text { (purchased loyalists) }\end{array}$ & $\begin{array}{l}\text { Byggja endurkaupaákvörðun á fríðindum sem fást vegna } \\
\text { býðurtekinna kaupa. Munu líklega fara ef samkeppnisaðili }\end{array}$ \\
$\begin{array}{l}\text { Ánægju trygglyndi } \\
\text { (satisfied loyalists) }\end{array}$ & $\begin{array}{l}\text { Pörfum viðskiptavinanna er mætt og ánægjan heldur } \\
\text { sambandinu gangandi. Pessir viðskiptavinir horfa pó til verðsins } \\
\text { og skoða hvað aðrir bjóða. }\end{array}$ \\
Postular (apostles) & $\begin{array}{l}\text { Sterk tilfinningatengsl sem oft byggja á persónulegu sambandi. } \\
\text { Líta ekki til samkeppnisaðila. Eru öflugir talsmenn fyrirtækisins. }\end{array}$ \\
\hline
\end{tabular}

Pó fangar séu ekki tryggir samkvæmt skilgreiningu Curasi og Kennedy (2002) pá benda peir á að hugsanlega sé hægt að gera pá viðskiptavini trygga með pví að uppfylla parfir peirra betur. Pað getur skipt fyrirtæki miklu máli ef markaðsaðstæður breytast snögglega og í stað fákeppni ríki samkeppni (Jones og Sasser, 1995). Fáskiptið trygglyndi býður upp á mikla möguleika fyrir stjórnendur fyrirtækja pví pó viðskiptavinir í peim flokki séu ekki ánægðir pá eru engin veruleg vandamál til staðar, oft einungis hár skiptikostnaður (Curasi og Kennedy, 2002). Neikvæð áhrif slíkra viðskiptavina á hagnað fyrirtækja koma ekki endilega strax í ljós en áframhaldandi óánægja getur valdið neikvæðum ummælum eða brottfalli viðskiptavina sem getur leitt til minni hagnaðar (Hirschman, 1970). Með réttum markaðsaðgerðum getur pví skapast gott tækifæri til að ná viðskiptavinum úr fáskiptu trygglyndi yfir í ánægjutrygglyndi (Curasi og Kennedy, 2002). Ekki er pó endilega jákvætt að halda í alla viðskiptavini í pessum flokki. Óánægðir viðskiptavinir sem gera óraunhæfar kröfur og parfir sem henta ekki getu fyrirtækis geta auðveldlega purrkað upp auðlindir pess og haft neikvæð áhrif á starfsanda (Jones og Sasser Jr., 1995). Fyrirtæki með viðskiptavini sem flokka má til ánægjutrygglyndis purfa stanslaust að mæta eða fara fram úr væntingum viðskiptavina sinna og viðhalda pannig ánægju peirra (Curasi og Kennedy, 2002).

\section{Mögulegur ávinningur tryggðar}

Aukinn áhuga fræðimanna og ekki síður stjórnenda á tryggð á síðustu tveimur til premur áratugum má líklega einna helst rekja til pess að fjöldi rannsókna hefur sýnt fram á jákvætt samband milli tryggðar og jákvæðs árangurs fyrirtækja á ýmsum sviðum. Tryggð viðskiptavina hefur t.d. reynst hafa jákvæð áhrif á hagnað sem kemur fyrst og fremst til vegna lægri kostnaðar við markaðssetningu, aukinnar sölu og lægri rekstrarkostnaðar (Bowen og Chen, 2001; Colgate og Norris, 2001; Reichheld og Sasser, 1990). Tryggir viðskiptavinir eru ólíklegri til að flytja viðskipti sín vegna 
lægra verðs annars staðar og eru jafnframt ólíklegri til að færa viðskipti sín pó upp komi tilfallandi mistök hjá fyrirtækinu (Colgate og Norris. 2001; Reichheld og Sasser, 1990).

Tryggir viðskiptavinir kaupa almennt meira af vörum og/eða pjónustu fyrirtækisins en peir sem eru minna tryggir og eru jafnvel tilbúnir til að greiða hærra verð fyrir vöruna/pjónustuna en aðrir (Martín-Consuegra, Molina og Esteban, 2007; Rauyruen o.fl., 2009; Reichheld og Sasser, 1990). Pá hefur verið sýnt fram á að vegna slíkrar aukinnar sölu leiði tryggð til aukningar í markaðshlutdeild (Chaudhuri og Holbrook, 2001)

Tryggir viðskiptavinir stunda einnig oft og tíðum öflugt kynningarstarf fyrir fyrirtæki, t.d. með jákvæðu umtal um fyrirtækið, vörur og/eða pjónustu pess, eru gjarnir á að mæla með fyrirtækinu við aðra og ráðleggja jafnvel öðrum varðandi ýmislegt sem tengist fyrirtækinu, vörum pess og pjónustu (Bowen og Chen, 2001; Reichheld og Sasser, 1990). Tryggir viðskiptavinir eru að pví leiti ein besta auglýsing sem fyrirtæki geta fengið. Peir hafa verið taldir vinna með markvissari hætti með fyrirtækjum en peir sem eru ótryggir sem leiðir til gagnkvæms ávinnings fyrir báða aðila (Gil-Saura, Frasquet-Deltoro og Cervera-Taulet, 2009).

Lægri rekstarkostnaður í tengslum við trygga viðskiptavini kemur aðallega til vegna pess að peir pekkja vörur, pjónustu og ferla fyrirtækisins vel og purfa pví minni upplýsingar en ella og pví kostar alla jafna minna að pjónusta pá (Bowen og Chen, 2001; Colgate og Norris, 2001; Curasi og Kennedy, 2002; Mittal og Lasser, 1998; Reichheld og Sasser, 1990; Rust og Zahorik, 1993). Par sem tryggð endurspeglar oft hversu líklegt sé að viðskiptavinur haldi áfram viðskiptum eða skipti yfir til samkeppnisaðila má segja að aukning í tryggð dragi úr ógn af samkeppni (Rauyruen o.fl., 2009). Tryggð er pví álitin hafa mikilvæg áhrif á heildarframmistöðu fyrirtækis og er talin grunnur að samkeppnisforskoti (Woodruff, 1997).

prátt fyrir að flestir rannsakendur aðhyllist pá skoðun að tryggir viðskiptavinir séu ákjósanlegir, hafa verið settar fram efasemdir um að slíkir viðskiptavinir séu eins fýsilegir og af er látið. Reinartz og Kumar (2002) eru meðal peirra sem hafa sett töluverða varnagla um að tryggð sé í raun eins mikil gæfa fyrir fyrirtæki og margir telja. Samkvæmt peirra rannsóknum er samband tryggðar og hagnaðar töluvert veikara en margir hafa haldið fram. Peir segja að pað séu litlar eða jafnvel engar vísbendingar um að ódýrara sé að pjónusta trygga viðskiptavini, að peir séu minna viðkvæmir fyrir verðbreytingum eða að peir séu sérstaklega árangursríkir í að draga að ný viðskipti. Á fyrirtækjamarkaði er algengt að viðskiptavinir sem hafa verið lengi í viðskiptum ætlist til að fá lægra verð en aðrir, að öðrum kosti fari peir annað með viðskipti sín (Gardener og Trivedi, 1998; Reinartz og Kumar, 2002). Рað má pví búast við pví að verðteygni á fyrirtækjamarkaði sé nokkuð mikil og að fyrirtæki séu líkleg til að skipta um pjónustuveitanda bjóðist peim lægra verð annars staðar.

Prátt fyrir að efasemdir hafi verið settar fram um ávinning tryggðar er mikill meirihluti fræðimanna sem telur áhrif tryggðar á rekstur fyrirtækja ótvírætt jákvæð (sjá t.d. Bowen og Chen, 2001; Chaudhuri og Holbrook, 2001; Colgate og Norris, 2001; Gil-Saura o.fl, 2009; Martín-Consuegra o.fl., 2007; Rauyruen o.fl., 2009; Reichheld og Sasser, 1990). 


\section{$5 \quad$ Ánægja viðskiptavina skilgreind}

Ánægja viðskiptavina hefur löngum verið viðurkennd sem mikilvægur páttur í kauphegðun (Ranaweera og Prabhu, 2003; Zahorik og Rust, 1992). Zeithaml, Berry og Parasuraman (1993) skilgreina ánægju viðskiptavina sem pann mun sem er á milli væntinga viðskiptavina og skynjunar peirra á pví sem peir fá frá fyrirtækinu. Skilgreining pessara áhrifamiklu rannsakenda pjónustufræðanna má segja að byggi á hinu pekkta væntingalíkani (expectationcy disconfirmation model) Oliver (1977) par sem ánægja er talin leiða af samanburði á upphaflegum væntingum og raunverulegum niðurstöðum. Ánægjan ræðst pví annars vegar af pví við hverju viðskiptavinir búast og hins vegar af pví hver frammistaða fyrirtækisins og starfsfólks er, pegar viðskiptin fara fram. Pví má segja að ánægja viðskiptavina segi til um hversu vel væntingum peirra er mætt (Oliver, 1999). Ef skynjuð gæði eru eins og búist var við eða meiri verður viðskiptavinurinn ánægður, en ef skynjuð gæði eru lakari en búist var við verður viðskiptavinurinn óánægður (Espejel, Fandos og Flavián, 2008). Ánægju viðskiptavina má pví líta á sem heildstætt hugrænt mat sem byggir á reynslu viðskiptavinanna í samanburði við pað sem peir væntu (Helgesen og Nesset, 2007).

Sumir hafa skilgreint ánægju viðskiptavina nokkuð víðar og almennar. Woodruff (1997) skilgreinir ánægju sem heildaránægju byggða á tilfinningu og mati viðskiptavinarins á einu eða fleiri reynslutilvikum. Hellier o.fl. (2003) segja ánægju heildarstig gleði sem viðskiptavinur upplifir og verður til vegna getu til að uppfylla langanir, væntingar og parfir viðkomandi viðskiptavinar. Í svipaðan streng taka Olsen, Wilcox og Olsson (2005) sem tala um ánægju sem heildstætt mat eða tilfinningu gagnvart vöru eða pjónustu.

Við mat á ánægju er ýmist hægt að horfa til einstakra viðskipta eða til uppsafnaðrar skynjunar viðskiptavina. Samkvæmt Gil-Saura o.fl, (2009) er eðlilegra að horfa til hinnar uppsöfnuðu skynjunar við mat á ánægju viðskiptavina á fyrirtækjamarkaði

\section{Samband ánægju og tryggðar}

Раð аð uppfylla parfir og langanir viðskiptavina og par með gera pá ánægða, hefur verið talinn lykilpáttur í að skapa trygga viðskiptavini (Ranaweera og Prabhu, 2003). Ánægja er pví forsenda pess að tryggð myndist hjá viðskiptavinum (Anderson o.fl., 1994; Oliver, 1999). Í sumum rannsóknum hefur ánægja reynst vera beinn áhrifapáttur á tryggð (sjá t.d. Caceres og Paparoidamis, 2007; Espejel o.fl., 2008; Helgesen og Nesset, 2007; Gil-Saura o.fl., 2009) en í öðrum hafa niðurstöður leitt í ljós óbein áhrif ánægju á tryggð í gegnum priðju breytu (sjá t.d. Davis-Sramek o.fl., 2009; Helgesen og Nesset, 2011; Hellie o.fl., 2003). Hún er nauðsynlegt forsenda, en ekki nægjanleg forsenda. Pannig eru tryggir viðskiptavinir almennt ánægðir, en ánægðir viðskiptavinir eru ekki endilega tryggir (Oliver, 1999). Taka má sem dæmi viðskiptavin sem á sín fyrstu viðskipti við tiltekið fyrirtæki. Viðskiptavinurinn getur orðið afar ánægður eftir viðskiptin, p.e.a.s. viðskiptin stóðu undir væntingum hans og jafnvel vel pað. Hann verður hins vegar vart tryggur eftir pessi fyrstu viðskipti, 
enda myndast og próast tryggð yfir tíma (Mattila, 2004).

Niðurstöður rannsóknar Back og Parks (2003) sýndu að ánægja viðskiptavina hafði jákvæð áhrif á hugræna tryggð, en hafði hins vegar ekki bein áhrif á hegðunartryggð. Áhrif ánægju á hegðunartryggð reyndust aðeins vera í gegnum hugræna tryggð. Miðað við pessar niðurstöður má draga pá ályktun að ánægðir viðskiptavinir séu ekki líklegir til endurtekinna viðskipta nema hugræn tryggð hafi myndast.

Sambandið milli ánægju og tryggðar virðist í flestum tilfellum vera ólínulegt (Bowen og Chen, 2001; Olivia, Oliver og MacMillan, 1992) sem pýðir að lítil breyting á ánægju getur valdið verulegri breytingu á tryggð.

\subsection{Rannsóknartilgátur}

Sumir rannsakendur hafa einblínt á ætluð endurkaup (repurchase intentions) sem er mat einstaklings á líkunum á að kaupa aftur tiltekna pjónustu frá sama fyrirtæki par sem tekið er tillit til núverandi aðstæðna viðkomandi einstaklings og líklegra kringumstæðna (Hellier o.fl., 2003). Svo virðist sem óánægja sé yfirleitt helsta ástæða pess að viðskiptasambandi er hætt (Pick, 2010), en rannsóknir hafa sýnt misvísandi niðurstöður um hvort áhrif ánægju á endurkaup séu bein eða óbein. Niðurstöður Hellier o.fl. (2003) bentu til pess að ánægja hefði ekki bein áhrif á endurkaup, heldur væru áhrifin óbein í gegnum markvisst val vörumerkis umfram önnur (brand preference). Í rannsókn Espejel o.fl. (2008) komu hins vegar fram mikil áhrif ánægju á endurkaup og reyndust tengslin bæði jákvæð og mjög sterk. Pví er eftirfarandi tilgáta sett fram:

H1: Jákvæð tengsl eru á milli ánægju viðskiptavina með pjónustu og ætlaðra endurkaupa.

Umtal viðskiptavina (word of mouth) hefur verið talinn einn af peim páttum sem skiptir máli pegar kemur að tryggð. Söderlund (1998) skilgreinir umtal sem pað hátterni viðskiptavina að upplýsa vini, ættingja og samstarfsaðila um tilvik sem hefur skapað ánægju hjá viðskiptavininum. Ef viðskiptavinir eru tilbúnir til að tala á jákvæðan hátt um fyrirtæki, pjónustu pess og/eða vörur eru peir að sýna sterk tilfinningaleg tengls við fyrirtæki og sanna tryggð (Ranaweera og Prabhu, 2003). Rannsóknir hafa sýnt tengsl og áhrif ánægju á umtal viðskiptavina um fyrirtæki (Ranaweera og Prabhu, 2003; Söderlund, 1998). Hins vegar bendir flest til pess að viðskiptavinir séu gjarnari á að segja frá neikvæðri reynslu sinni heldur en jákvæðri og séu pví líklegri til neikvæðs umtals, hafi peir orðið óánægðir með pjónustu fyrirtækis (sjá t.d. Hart, Heskett og Sasser, 1990, Fisk, Brown, Cannizzaro og Naftal, 1990; Söderlund, 1998). Í ljósi pessa er eftirfarandi tilgáta sett fram:

H2: Neikvæð tengsl eru á milli ánægju viðskiptavina með pjónustu og neikvæðs umtals um fyrirtækið.

Meðmæli með fyrirtæki eða vörum pess hefur jafnframt pótt vera einn af peim páttum sem einkennir trygga viðskiptavini. Rannsókn Wangenheim og Bayón (2007) sýndi jákvæð áhrif ánægju á meðmæli með fyrirtækinu og að slíkt hefði pau áhrif að nýir aðilar kæmu í viðskipti við fyrirtækið. Pví er eftirfarandi tilgáta sett fram: 
H3: Jákvæð tengsl eru á milli ánægju viðskiptavina

með pjónustu og meðmæla með fyrirtækinu.

Rannsókn Homburg, Hoyer og Koschate (2005) leiddi í ljós að ánægja viðskiptavina dregur úr neikvæðum áhrifum verðhækkana á endurkaup, p.e.a.s. með aukinni ánægju viðskiptavina eru peir líklegri til að halda áfram að eiga viðskipti við fyrirtæki prátt fyrir að verð hækki. Niðurstöður Martína-Consuegra o.fl. (2007) sýndu að ánægðir viðskiptavinir eru tilbúnir að borga hærra verð fyrir pjónustu og aðrar rannsóknir hafa sýnt að eftir pví sem viðskiptavinir eru ánægðari peim mun minni er verðteygnin (Choi, Kim, Kim, Kim, 2006; Homburg o.fl., 2005). Par af leiðandi er eftirfarandi tilgáta sett fram:

H4: Jákvæð tengsl eru á milli ánægju viðskiptavina með pjónustu og endurkaupa pó sama pjónusta sé ódýrari annars staðar.

\section{Aðferð}

Hér verður fjallað um aðferðafræði rannsóknarinnar; mælitækinu lýst, gerð grein fyrir pátttakendum og ásamt pví að framkvæmdin verður útlistuð.

\subsection{Mælitæki}

Prátt fyrir að almenn samstaða sé orðin um að tryggð viðskiptavina samanstandi af hegðunarvídd og hugrænni vídd er verulegur skortur á almennri og góðri nálgun við mælingar á tryggð (Baumann o.fl., 2005; McMullan, 2005; Odin o.fl., 2001; Reichheld, 2003; Söderlund, 2006; Rundle-Thiele og Mackay, 2001). Fjölbreyttar aðferðir hafa verið notaðar til að mæla tryggð, en algengast er að aðeins fáir pættir hvorrar víddar séu notaðir og jafnvel er eitthvað um pað enn í dag að rannsakendur láti nægja að mæla áform um áframhaldandi viðskipti og álykta um tryggð út frá pví (sjá t.d. Friðrik Eysteinsson og Pórhallur Guðlaugsson, 2010). Mælitæki rannsóknarinnar var pví frumsaminn spurningalisti, en hann var pó saminn með hliðsjón af ýmsum rannsóknum, m.a. Mattila (2004) og Skogland og Siguaw (2004).

Ánægja viðskiptavina með pjónustuna var metin með einu atriði (single-item) par sem pátttakendur voru beðnir um að tilgreina hversu ánægðir peir væru heilt á litið með pjónustu Fyrirtækisins. Svarkostir voru á 5 punkta Likert kvarða par sem 1 táknaði að pátttakendur væru mjög óánægðir, 2 táknaði að peir væru óánægðir, 3 táknaði að peir væru hlutlausir, 4 táknaði að peir væru ánægðir og 5 táknaði að peir væru mjög ánægðir. Allir svarmöguleikar voru merktir með orðagildum, enda hafa rannsóknir bent til pess að matskvarðar séu áreiðanlegri pegar pað er gert (Alwin og Krosnick, 1991; Boote, 1981). Prátt fyrir að ánægja sé oft metin með nokkrum atriðum (multi-item) hafa ýmsir farið pá leið að láta pátttakendur meta heildar ánægju með einni breytu (sjá t.d. Caceres og Paparoidamis, 2007; Mittal, Ross og Baldesare, 1998). Auk pess hefur Yi (1990) borið saman matskvarða á ánægju par sem annars vegar er notað eitt atriði og hins vegar nokkur atriði og niðurstöður hans sýndu að ásættanlegt réttmæti fæst með notkun á einu atriði til að leggja mat á ánægju. 
Fjögur atriði voru notuð til að leggja mat á tryggð. Ákveðið var að taka ekki afstöðu til pess hvort pau atriði tengjast hugrænni vídd eða hegðunarvídd. Ástæðan er annars vegar sú að markmið rannsóknarinnar er ekki að kanna víddir tryggðar sérstaklega eða tengsl peirra við ánægju og hins vegar sú að rannsakendur hafa ekki sammælst um hvaða atriði ber að flokka í hvora vídd. Algengt er að rannsakendur leggi mat á tryggð með nokkrum atriðum, án pess að tilgreina sérstaklega hvaða vídd pau tilheyra, prátt fyrir að viðurkennt sé að um margvítt hugtak er að ræða. pau atriði sem voru notuð til að leggja mat á tryggð voru eftirfarandi:

- Hversu ólíklegt eða líklegt er að pú mælir með Fyrirtækinu við aðra?

- Hversu ólíklegt eða líklegt er að pú skiptir við Fyrirtækið næst pegar pú kaupir prentpjónustu?

- Hversu ólíklegt eða líklegt er að pú skiptir við Fyrirtækið pó sama pjónusta sé ódýrari annars staðar?

- Hversu ólíklegt eða líklegt er að pú talir á neikvæðan hátt um Fyrirtækið við aðra?

Tryggðarspurningarnar voru allar á 5 punkta Likert kvarða par sem 1 táknaði mjög ólíklegt, 2 táknaði ólíklegt, 3 táknaði hlutlaus, 4 táknaði líklegt og 5 táknaði mjög líklegt. Allir svarkostir voru merktir með orðagildum. Í eldri rannsóknum á viðfangsefninu er algengt að notaður sé 7 punkta kvarði (sjá t.d. Back og Parks, 2003; Chadhuri og Holbrook, 2001; Choi o.fl., 2006; Davis-Sramek o.fl., 2009; Espejel o.fl., 2008; Homburg o.fl., 2005; Martín-Consuegra o.fl., 2007; Renaweera og Prabhu, 2003), pó vissulega hafi sumir notað 5 punkta kvarða (sjá t.d. Gil-Saura o.fl., 2009; Rauyruen o.fl., 2009). Rannsakendur ákváðu að nota 5 punkta kvarða og voru helst tvær ástæður fyrir pví: Annars vegar vegna pess að peir töldu að svarkostir yrðu of margir með notkun 7 punkta kvarða og að hugsanlega myndi tilviljun ráða pví hvort pátttakendur merktu við t.d. 5 eða 6 af 7 mögulegum, fremur en að um raunverulegan mun á afstöðu væri að ræða. Hins vegar horfðu rannsakendur til niðurstaðna Dawes (2008) sem sýndu ekki mun á niðurstöðum úr 5 punkta kvarða annars vegar og 7 punkta kvarða hins vegar.

Við úrvinnslu var síðustu spurningunni snúið við til að samræmi væri í tryggðarspurningunum, par sem tölugildið 1 í peirri spurning var í raun jákvætt en tölugildið 5 í raun neikvætt. Við mat á heildartryggð voru tryggðarbreyturnar allar settar saman í eina breytu par sem breyturnar höfðu allar sama vægi. Áreiðanleiki samsettu tryggðarbreytunnar reyndist lægri en ákjósanlegt hefði verið, par sem Cronbach's $\alpha=0,656$, en ákjósanlegra hefði verið að $\alpha$ gildið næði 0,7 (Field, 2009). Breyturnar reyndust pó allar leggja sitt af mörkum til áreiðanleikans par sem $\alpha$ hefði ekki verið hærra af einhverjum af breytunum hefði verið sleppt (Chronbach's $\alpha$ if Item is deleted var í öllum tilvikum lægra en 0,656). Jafnframt var innri fylgni breytanna (corrected item-total correlation) í öllum tilvikum hærri en 0,3. Field (2009) leggur áherslu á að fjöldi breyta hafi mikil áhrif á Cronbach's $\alpha$ par sem gildið hækkar alla jafna pegar breyturnar eru fleiri en er líklegra til að vera lágt pegar breyturnar eru fáar. Í pessari mælingu eru breyturnar aðeins fjórar, sem kann að skýra lágt $\alpha$ gildi. Pó er rétt að nefna að lágt $\alpha$ gildi kunni að skýrast af pví að atriðin séu ekki að mæla sömu hugsmíðina. Vert er að kanna pað nánar og gera viðeigandi ráðstafanir hvað petta varðar í frekari rannsóknum á viðfangsefninu. 
Ytra réttmæti rannsóknarinnar er ekki mjög sterkt par sem einungis eitt fyrirtæki er til skoðunar. Hins vegar er pað fyrirtæki sem um ræðir stórt á fyrirtækjamarkaði með prentpjónustu. Рað er ekki óalgengt að í sambærilegum rannsóknum sé aðeins eitt fyrirtæki til skoðunar (sjá t.d. Cugini o.fl., 2010; Lam o.fl., 2004; Taylor og Hunter, 2003).

\subsection{Dátttakendur}

Úrtakið samanstóð af peim viðskiptavinum sem eru á netfangalista Fyrirtækisins og eru með sérstakan tengilið sem sér um pantanir eða innkaup. Um er að ræða stóran meirihluta peirra viðskiptavina sem eiga reglulega viðskipti við Fyrirtækið. Á netfangalistanum voru 912 netföng en í ljós kom að 60 netföng voru óvirk og í 10 tilfellum kom svar til baka um að viðkomandi væri í fríi á meðan á rannsókninni stóð. Virk og nothæf netföng voru pví 842. Pátttakendur voru 352 og var svarhlutfall pví 41,8\%. Í töflu 2 má sjá upplýsingar um pátttakendur.

Tafla 2. Upplýsingar um pátttakendur

\begin{tabular}{lrlr}
\hline Staða & & \multicolumn{2}{l}{ Starfsmannafjöldi } \\
\hline Forstjóri/eigandi & $12,3 \%$ & 10 eða færri & $32,2 \%$ \\
Framkvæmdastjóri & $22,5 \%$ & 11 til 50 & $26,3 \%$ \\
Markaðsstjóri & $9,0 \%$ & 51 til 100 & $11,9 \%$ \\
Innkaupastjóri & $12,3 \%$ & 100 eða fleiri & $26,3 \%$ \\
Framleiðslustjóri & $8,1 \%$ & Vill ekki svara & $3,3 \%$ \\
Frjámálastjóri & $1,8 \%$ & & \\
Skrifstofustjóri & $1,2 \%$ & & \\
Deilda-, sölu- eða verkefnastjóri & $8,1 \%$ & & \\
Annað/vill ekki svara & $24,7 \%$ & & \\
\hline
\end{tabular}

\subsection{Framkvæmd}

Í upphafi var leitað eftir samstarfi við Fyrirtækið og veitti framkvæmdastjóri fyrirtækisins sampykki fyrir að rannsóknin yrði framkvæmd. Pegar mælitækið hafði verið mótað var pað forprófað á sex einstaklingum á ólíkum aldri, með ólíka menntun og ólíkan bakgrunn. Tveir pátttakenda í forprófun voru háskólanemendur með reynslu í gerð og uppsetningu spurningalista, einn pátttakandi hafði átt í viðskiptum við Fyrirtækið, en hinir prír pátttakendurnir í forprófuninni pekktu ekki vel til peirra hugtaka sem notuð voru, en peirra pátttaka var talin mikilvæg til að kanna hvort peir skildu vel pað sem um var spurt. Engar athugasemdir voru gerðar við forprófun og pví talið að skilningur á orðalagi og merkingu væri góður. Að lokum var mælitækið skoðað og sampykkt af framkvæmda, sölu- og markaðsstjóra fyrirtækisins.

Fyrirlögnin fór fram í júní 2011 og var rafræn. Spurningalistinn var sendur út á tölvupóstföng af netfangalista Fyrirtækisins. Tvær ítrekanir voru sendar með von um að auka svarhlutfall og við báðar ítrekanir jóks svörun. 


\section{$8 \quad$ Niðurstöður}

Pátttakendur virðast almennt fremur ánægðir með pjónustu Fyrirtækisins ( $\mathrm{M}=3,87$; sf=1,207; N=347). Í töflu 3 má sjá niðurstöður úr tryggðarbreytunum fjórum. Par má sjá að heildartryggðin, p.e. samsett breyta úr tryggðarbreytunum fjórum, bendir til ágætrar tryggðar við fyrirtækið. Priðja breytan kemur verst út, p.e.a.s. pátttakendur virðast nokkuð líklegir til að færa viðskipti frá Fyrirtækinu ef pjónustan er ódýrari annars staðar, sem kann að vera áhyggjuefni og bera vott um að tryggðin sé í raun ekki mjög djúpstæð.

Tafla 3. Niðurstaða úr tryggðarbreytum

\begin{tabular}{lccc}
\hline Hversu ólíklegt eða líklegt er að pú ... & M & sf & N \\
\hline $\begin{array}{l}\text {... mælir með Fyrirtækinu við aðra? } \\
\begin{array}{l}\text {.. skiptir við Fyrirtækið næst pegar pú } \\
\text { kaupir pjónustu? }\end{array}\end{array}$ & 3,98 & 0,982 & 347 \\
$\begin{array}{l}\text {... skiptir við Fyrirtækið pó sama } \\
\text { pjónusta sé ódýrari annars staðar? }\end{array}$ & 2,72 & 1,124 & 340 \\
$\begin{array}{l}\text {... talir á neikvæðan hátt um } \\
\text { Fyrirtækið við aðra? }\end{array}$ & 1,72 & 0,826 & 342 \\
\begin{tabular}{l} 
Tryggð \\
\hline
\end{tabular} & 3,73 & 0,688 & 338 \\
\hline
\end{tabular}

Kvarði: 5 = Mjög líklegt, 1 = Mjög ólíklegt

Tengsl á milli breyta voru könnuð með Pearson-r og miðað við skilgreiningu Field (2005) á styrkleika tengslanna. Samkvæmt honum er um veika fylgni að ræða ef r er undir 0,30, um miðlungs fylgni að ræða ef $\mathrm{r}$ er á bilinu 0,30 til 0,49 og um sterka fylgni að ræða ef r er yfir 0,50.

Í töflu 4 má sjá tengsl ánægju og sérhverrar tryggðarbreytu, auk tengsla ánægju og heildartryggðar, par sem búið var að útbúa eina tryggðarbreytu úr tryggðarbreytunum fjórum. Niðurstöðurnar sýna að prátt fyrir að fylgni á milli heildaránægju og heildartryggðar teljist marktæk pá er hún veik.

Jákvæð tengsl eru milli ánægju með pjónustuna og ætlaðra endurkaupa. $\mathrm{H}_{1}$ er pví studd, en um veik tengsl er að ræða. $\mathrm{H}_{2}$ er jafnframt studd par sem neikvæð tengsl eru á milli ánægju og neikvæðs umtals um fyrirtækið. Tengslin eru pó afar veik. Jafnframt fékkst stuðningur við $\mathrm{H}_{3}$ par sem jákvæð tengsl reyndust vera á milli ánægju með pjónustuna og meðmæla með fyrirtækinu. Tengslin á milli pessara breyta voru miðlungs sterk og reyndust vera sterkustu tengslin sem mældust. Ekki fékkst stuðningur við $\mathrm{H}_{4}$ par sem ekki mældust tengsl milli ánægju og ætlaðra endurkaupa pegar pjónustan er ódýrari annars staðar. 
Tafla 4. Fylgni milli breyta

\begin{tabular}{|c|c|c|c|c|c|c|c|}
\hline & & $\begin{array}{c}\text { Heildaránægja } \\
\text { með pjónustu } \\
\text { Fyrirtækisins }\end{array}$ & $\begin{array}{c}\text { Líkur á að } \\
\text { mæla með } \\
\text { Fyrirtækinu } \\
\text { við aðra }\end{array}$ & \begin{tabular}{|c|} 
Líkur á að \\
skipt verði við \\
Fyrirtækið \\
næst pegar \\
pjónusta er \\
keypt
\end{tabular} & $\begin{array}{c}\text { Líkur á að } \\
\text { skipt verði við } \\
\text { Fyrirtækið pó } \\
\text { sama pjónusta } \\
\text { sé ódýrari } \\
\text { annars staðar }\end{array}$ & $\begin{array}{c}\text { Líkur á að tala } \\
\text { á neikvæðan } \\
\text { hátt um } \\
\text { Fyrirtækið við } \\
\text { aðra }\end{array}$ & Tryggð \\
\hline Heildaránægja með & Pearson fylgni & 1 &, $357^{* *}$ & ,231 ${ }^{\text {** }}$ & ,074 &,$- 139^{*}$ & $281^{* *}$ \\
\hline pjónustu & Sig. (2-tailed) & &, 000 &, 000 & 175 &, 010 & ,000 \\
\hline Fyrirtækisins & $N$ & 347 & 343 & 342 & 336 & 338 & 334 \\
\hline \multirow{3}{*}{$\begin{array}{l}\text { Líkur á að mæla með } \\
\text { Fyrirtækinu við aðra }\end{array}$} & Pearson fylgni &, $357^{* *}$ & 1 &, $599^{* *}$ & $254^{* *}$ &,$- 333^{* *}$ & $772^{* *}$ \\
\hline & Sig. (2-tailed) & ,000 & & ,000 & ,000 & ,000 &, 000 \\
\hline & $N$ & 343 & 347 & 345 & 339 & 341 & 338 \\
\hline \multirow{3}{*}{$\begin{array}{l}\text { Líkur á að skipt verði } \\
\text { við Fyrirtækið næst } \\
\text { pegar pjónusta er }\end{array}$} & Pearson fylgni & $231^{* *}$ &, $599^{* *}$ & 1 & $343^{* *}$ &,$- 286^{* *}$ & ,791 ${ }^{* *}$ \\
\hline & Sig. (2-tailed) &, 000 & ,000 & &, 000 & ,000 & ,000 \\
\hline & $N$ & 342 & 345 & 346 & 340 & 342 & 338 \\
\hline \multirow{3}{*}{$\begin{array}{l}\text { Líkur á að skipt verði } \\
\text { við Fyrirtækið pó } \\
\text { sama pjónusta sé }\end{array}$} & Pearson fylgni & , 074 & $254^{* *}$ & $343^{* *}$ & 1 &,$- 136^{*}$ & $662^{* *}$ \\
\hline & Sig. (2-tailed) & ,175 & ,000 &, 000 & &, 012 & ,000 \\
\hline & $N$ & 336 & 339 & 340 & 340 & 339 & 338 \\
\hline \multirow{3}{*}{$\begin{array}{l}\text { Líkur á að tala á } \\
\text { neikvæðan hátt um } \\
\text { Fyrirtækið við aðra }\end{array}$} & Pearson fylgni &,$- 139^{*}$ &,$- 333^{* *}$ &,$- 286^{* *}$ &,$- 136^{*}$ & 1 &,$- 574^{* *}$ \\
\hline & Sig. (2-tailed) &, 010 & ,000 &, 000 & ,012 & &, 000 \\
\hline & $N$ & 338 & 341 & 342 & 339 & 342 & 338 \\
\hline \multirow[t]{3}{*}{ Tryggð } & Pearson fylgni & $281^{* *}$ &, $772^{* *}$ &, $791^{* *}$ &, $662^{* *}$ &,$- 574^{* *}$ & 1 \\
\hline & Sig. (2-tailed) & ,000 & ,000 &, 000 & ,000 &, 000 & \\
\hline & $N$ & 334 & 338 & 338 & 338 & 338 & 338 \\
\hline
\end{tabular}

Gögnin voru skoðuð nánar par sem meðalgildi hverrar tryggðarbreytu var kannað miðað við afstöðu til óánægju eða ánægju. Bent skal á að fjöldi svara við hvern svarkost óánægju-ánægju kvarðans var afar misjafn. Nokkuð fáir voru mjög óánægðir $(\mathrm{N}=29)$, óánægðir $(\mathrm{N}=23)$ og hlutlausir $(\mathrm{N}=31)$, en mun fleiri ánægðir (N=135 til 138) og mjög ánægðir ( $\mathrm{N}=120$ til 122).

Á mynd 1 má sjá niðurstöðurnar varðandi líkur á endurkaupum miðað við afstöðu til óánægju og ánægju. Eins og sjá má eru mestar líkur á endurkaupum við hæsta stig ánægju, en minnstar líkur pegar pátttakendur segjast hlutlausir.

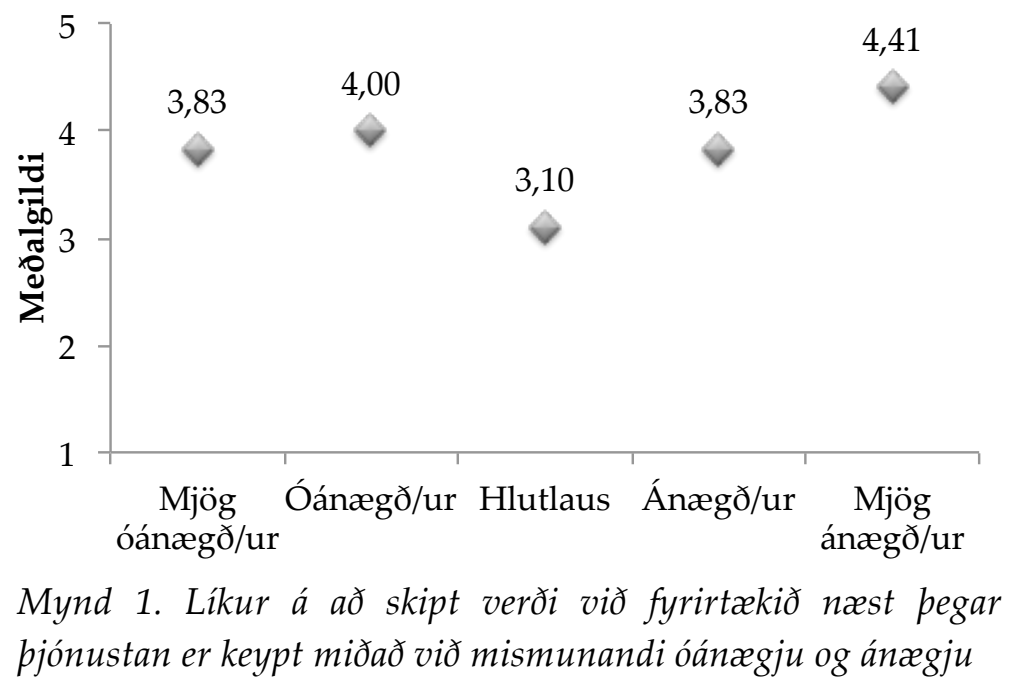

Mynd 2 sýnir niðurstöður varðandi líkur á neikvæðu umtali við ólíka afstöðu til ánægju. Athyglivert er að líkurnar eru minnstar á neikvæðu umtali annars vegar við 
hæsta stig ánægju og hins vegar við hæsta stig óánægju. Mestar líkur virðast vera á neikvæðu umtali frá peim sem segjast hlutlausir.

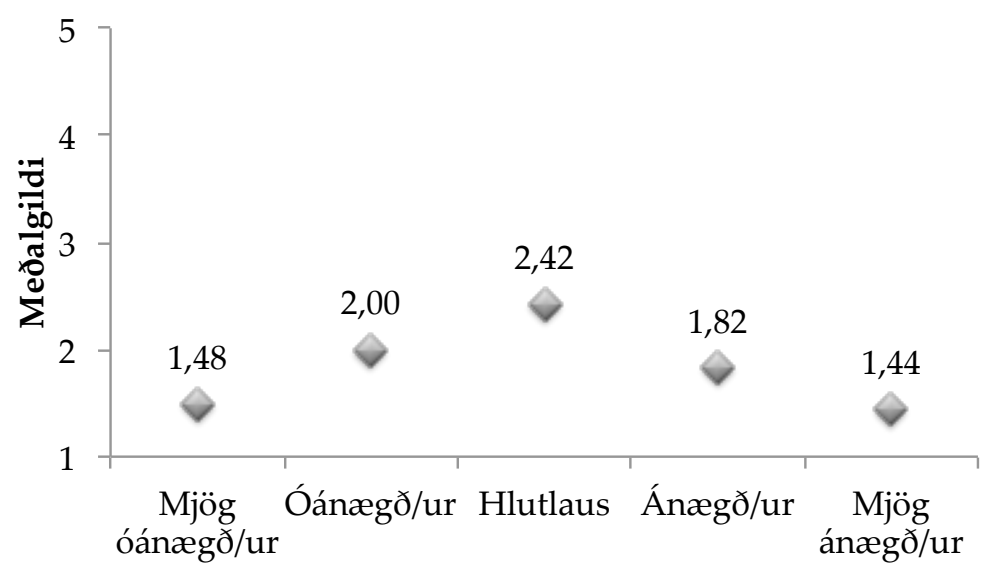

Mynd 2. Líkur á að talað verði á neikvæðan hátt um fyrirtækið við aðra miðað við mismunandi óánægju og ánægju

Mestar líkur eru á pví að peir sem segjast mjög ánægðir með pjónustuna mæli með fyrirtækinu við aðra, eins og sést á mynd 3. Ólíklegastir til að veita meðmæli eru peir sem segjast hlutlausir.

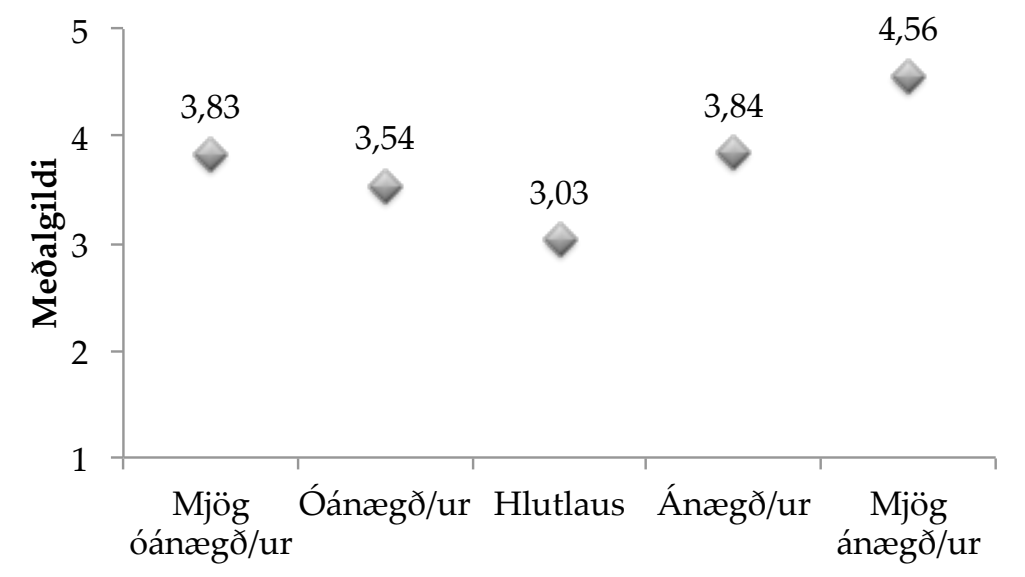

Mynd 3. Líkur á að mælt verði með fyrirtækinu við aðra miðað við mismunandi óánægju og ánægju

Athyglivert er að peir sem eru mjög óánægðir eru líklegastir til að versla við fyrirtækið pó sama pjónusta sé ódýrari annars staðar, líkt og sjá má á mynd 4 . Niðurstöðurnar benda til pess að nokkur verðteygni sé meðal pátttakenda par sem allir eru ýmist nálægt hlutleysi í afstöðu sinni eða nálægt pví að segja ólíklegt að peir myndu skipta við fyrirtækið ef ódýrari pjónusta er í boði annars staðar. 


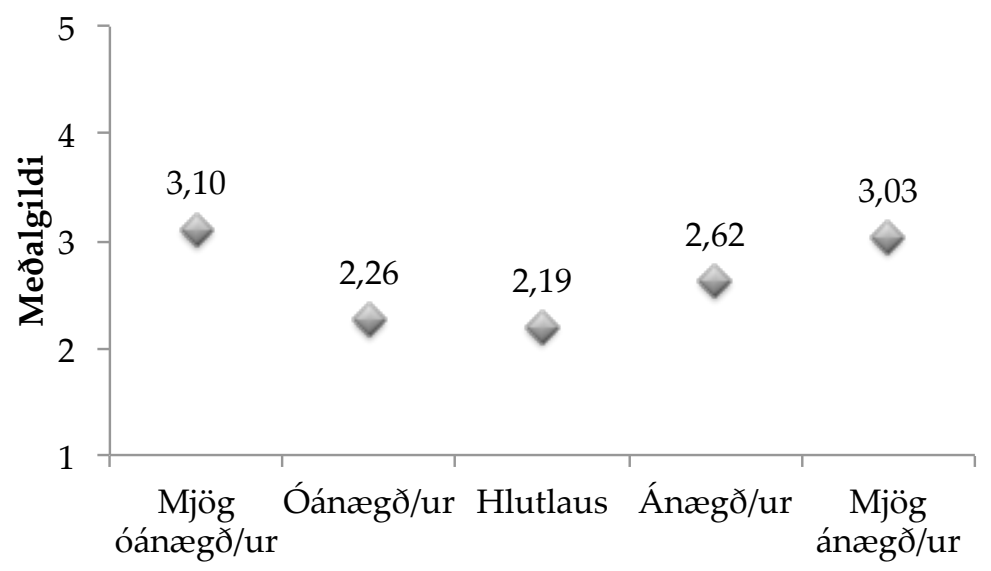

Mynd 4. Líkur á að skipt verði við fyrirtækið pó sama pjónusta sé ódýrari annars staðar miðað við mismunandi óánægju og ánægju

Á mynd 5 má sjá að peir sem eru ánægðastir með pjónustuna eru jafnframt tryggastir. Athyglisvert er að sjá hversu hátt stig tryggðar virðist vera hjá peim sem segjast mjög óánægðir með pjónustuna. Líkt og sjá má virðist sambandið milli ánægju og tryggðar vera ólínulegt.

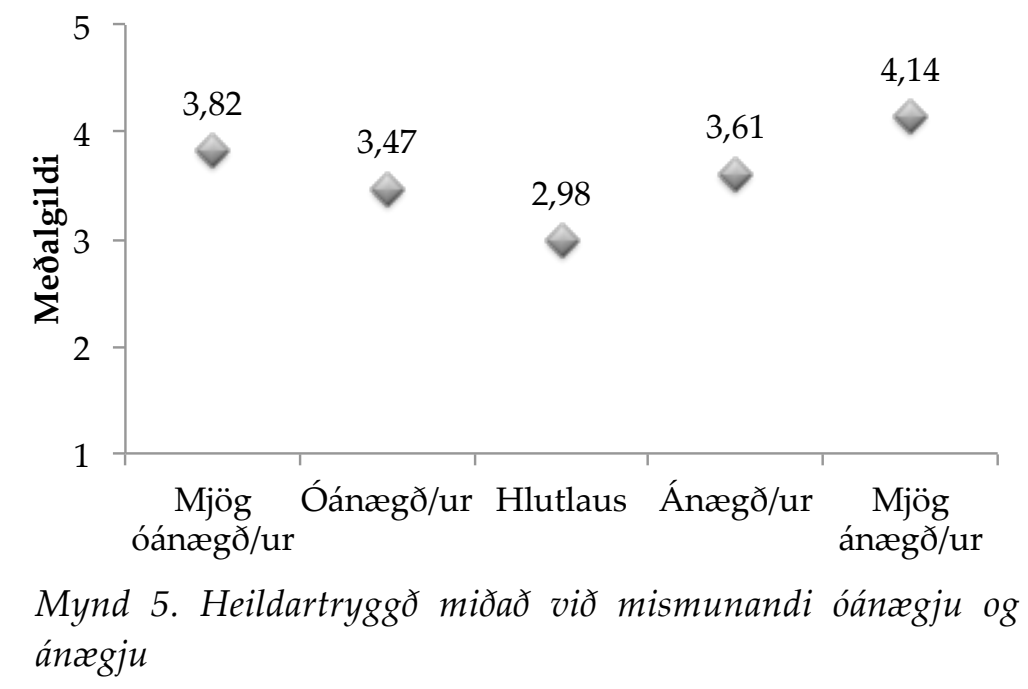

Pegar horft er á niðurstöður allra tryggðarbreytanna má sjá að pátttakendur sem segjast hlutlausir taka ávallt neikvæðustu afstöðuna. Pví má segja að pað sé sá hópur sem er hvað minnst tryggur. Jafnframt sést greinilega á myndum 1 til 5 að samband ánægju og tryggðabreytanna er í öllum tilvikum ólínulegt.

\section{Umræða}

Tryggð viðskiptavina hefur ýmiss konar jákvæð áhrif á fyrirtæki, m.a. á rekstrarkostnað (Colgate og Norris, 2001; Curasi og Kennedy, 2002), hagnað (Bowen 
og Chen, 2001; Reichheld og Sasser, 1990) og samkeppnisstöðu (Rauyruen o.fl., 2009). Pað ætti pví að vera kappsmál stjórnenda að fjölga peim viðskiptavinum sem eru tryggir. Óumdeilt er innan fræðasamfélagsins að ánægja er forsenda tryggðar (Anderson o.fl., 1994, Oliver, 1999). Samband pessarra breyta á einstaklingsmarkaði hefur verið viðfangsefni margra rannsókna, en hefur minna verið skoðað á fyrirtækjamarkaði. Markmið rannsóknarinnar var að kanna hversu sterk tengsl eru á milli ánægju viðskiptavina með pjónustu og tryggðar viðskiptavina í prentpjónustu. Niðurstöðurnar sýndu að tengsl ánægju og heildartryggðar voru jákvæð en pau voru veik. Peir viðskiptavinir sem sögðust ánægðastir reyndust jafnframt vera peir tryggustu, en sambandið milli breytanna reyndist ekki vera línulegt sem er í samræmi við fyrri rannsóknir (sjá t.d. Bowen og Chen, 2001; Olivia o.fl., 1992). Раð gefur stjórnendum verðmætar upplýsingar um mikilvægi pess að halda viðskiptavinum sem ánægðustum, ef ætlunin er að ná mikilli tryggð peirra.

Niðurstöðurnar sýndu jákvæð tengsl milli ánægju með pjónustu og ætlaðra endurkaupa, en tengslin reyndust veik. Рað er að hluta til í samræmi við niðurstöður Espejel o.fl. (2008), en í peirra rannsókn reyndust tengsl milli pessara breyta vera mjög sterk. Í pessari rannsókn reyndust líkur á endurkaupum vera nokkuð miklar óháð ánægju eða óánægju pátttakenda með pjónustuna. Ekki var spurt nánar út í ástæður pessa, p.e. hvers vegna peir sem ekki eru ánægðir með pjónustuna hyggjast samt sem áður halda viðskiptum áfram. •að kann hugsanlega að hluta til að skýrast af smægð pess markaðar sem um ræðir hér á landi og sterks stöðu pess fyrirtækis sem var til skoðunar.

Neikvæð tengsl reyndust vera á milli ánægju og neikvæðs umtals, en pau tengsl voru mjög veik. Peir viðskiptavinir sem sögðust ánægðastir með pjónustuna eru ólíklegastir til að tala á neikvæðan hátt um fyrirtækið, hins vegar er athyglisvert að peir sem sögðust óánægðastir með pjónustuna voru nánast jafn ólíklegir til að tala á neikvæðan hátt um fyrirtækið. Almennt virðast viðskiptavinirnir ólíklegir til að tala á neikvæðan hátt um fyrirtækið, hvort sem peir eru ánægðir eða óánægðir með pjónustuna. Pessar niðurstöður eru í nokkru ósamræmi við pað sem áður hefur verið haldið fram um að peir sem eru óánægðir með pjónustu séu líklegri til neikvæðs umtals (sjá t.d. Hart o.fl., 1990; Söderlund, 1998). Mögulega kann skýringin að felast í muni á fyrirtækjamarkaði annars vegar og einstaklingsmarkaði hins vegar. Hugsanlega eru viðskiptavinir á einstaklingsmarkaði, sem eru pá í persónulegum viðskiptum við fyrirtæki, líklegri til að tala á neikvæðan hátt ef peir verða óánægðir heldur en viðskiptavinir á fyrirtækjamarkaði, sem ekki eru í viðskiptunum vegna persónulegra nota á viðkomandi pjónustu. Petta pyrfti pó að skoða nánar.

Sterkustu tengslin reyndust vera á milli ánægju og meðmæla með fyrirtækinu, sem er í samræmi við niðurstöður Wangenheiim og Bayón (2007). Peir viðskiptavinir sem reyndust ánægðastir með pjónustuna voru töluvert líklegri en aðrir til að mæla með fyrirtækinu. Umtalsverður munur reyndist vera á líkum á meðmælum frá peim sem sögðust ánægðir annars vegar og mjög ánægðir hins vegar. Pessar upplýsingar eru gagnlegar fyrir stjórnendur og gefa tilefni til að ætla að pað skipti verulegu máli að ná mikilli ánægju viðskiptavina ef ætlunin er að nýta pá í að vinna með fyrirtækinu að öflugu kynningarstarfi.

Nokkur verðteygni virðist vera á markaðnum, pó vart sé hægt að segja út frá pessum niðurstöðum að hún sé mjög mikil. Рað sem pó ber að veita eftirtekt er að pað virðist ekki munur á verðteygni eftir pví hversu ánægðir eða óánægðir 
viðskiptavinir eru með pjónustuna, sem er gagnstætt rannsóknum Choi o.fl. (2006) og Homburg o.fl. (2005), en styður раð sem Gardener og Trivedi (1998) og Reinartz og Kumar (2002) hafa sett fram. Stjórnendur á pessum markaði purfa að gera sér grein fyrir að prátt fyrir að viðskiptavinir kunni að vera mjög ánægðir með pjónustuna geta verðhækkanir fyrirtækja eða verðlækkanir samkeppnisaðila orðið til pess að viðskiptavinir færi viðskipti sín. Tryggð viðskiptavina á markaðnum kann pví að flokkast undir tryggð byggða á ópersónulegum tengslum ef miðað er við Gremler og Brown (1998) eða ánægjutrygglyndi samkvæmt flokkun Curasi og Kennedy (2002).

Einn helsti lærdómur stjórnenda af niðurstöðum rannsóknarinnar kann að vera sá að ekki nægir að halda viðskiptavinum ánægðum ef ætlunin er að auka tryggð peirra og ná par með peim ávinningi og samkeppnisforskoti sem tryggð getur skapað. Stefna parf að mikilli ánægju meðal viðskiptavina, með mikilli áherslu á pjónustugæði, til að tryggð skapist.

\section{Takmarkanir og tillögur að frekari rannsóknum}

Hér var til skoðunar stórt og rótgróið fyrirtæki á prentmarkaði á Íslandi. Pað er pó vissulega takmarkandi páttur, til að hægt sé að álykta um markaðinn í heild, að aðeins eitt fyrirtæki var til skoðunar. Til að fá betri og sterkari mynd af markaðnum hefði verið gott að horfa til viðskiptavina fleirri fyrirtækja.

Í rannsóknum á viðfangsefninu er algengt að notast sé við 7 punkta kvarða, en hér var 5 punkta kvarði notaður. Pó niðurstöður Dawes (2008) hafi sýnt að ekki væri munur á niðurstöðum eftir pví hvort 5 eða 7 punkta kvarðar séu notaðir, væri áhugavert og gagnlegt að nota 7 punkta kvarða í samræmi við pað sem algengast er á sviðinu.

Við mat á ánægju var aðeins notað eitt atriði. Pó að Yi (1990) hafi komist að peirri niðurstöðu að ásættanlegt réttmæti fáist með notkun á einu atriði til að leggja mat á ánægju, kann pað að gefa betri og áreiðanlegri upplýsingar ef notast er við nokkur atriði. Rannsakendur mæla með að í frekari rannsóknum á viðfangsefninu verði pað gert.

Heildartryggð var metin með peim hætti að fjórar tryggðarbreytur voru settar saman og allar látnar hafa sama vægi. Áreiðanleiki heildartryggðar reyndist pó lægri en æskilegt hefði verið. Við frekari rannsóknir væri ákjósanlegt að taka fleiri tryggðarbreytur með í mælinguna til að freista pess að bæta áreiðanleikann við mat á heildartryggð. Önnur ástæða pess að æskilegt er að fjölga breytum í síðari rannsóknum við mat á heildartryggð er sú að prátt fyrir að algengt sé að fáar breytur séu notaðar við mat á tryggð, hefur lengi verið ljóst innan fræðasamfélagsins að tryggð er afar margvíð hugsmíð. Pví hlýtur að vera eðlilegt að meta hana með fleiri breytum. Vöntun er á góðu áreiðanlegu mælitæki til að leggja mat á tryggð viðskiptavina, pví væri ákjósanlegt að í frekari rannsóknum væru unnið að pví marki að próa slíkt mælitæki.

Samband ánægju og tryggðar hefur verið skoðað í töluvert minna mæli á fyrirtækjamarkaði heldur en á einstaklingsmarkaði. Sambandið kann að vera ólíkt á milli markaða, t.d. vegna aðstæðna og einkenna tiltekinna markaða. Рað er pví pörf á frekari rannsóknum á viðfangsefninu á fleiri fyrirtækjamörkuðum, bæði til að dýpka 
skilning á sambandi pessara breyta og jafnframt til að varpa ljósi á mögulegan mun á milli markaða.

\section{Heimildir}

Ajzen, I. og Fishbein, M. (1980). Understanding attitudes and predicting social behaviour. New Jersay: Prentice-Hall.

Alwin, D. F. og Krosnick, J. A. (1991). The reliability of survey attitude measurement: The influence of question and respondents attributes. Sociological Methods and Research, 20(1), 139-181.

Anderson, E. W., Fornell, C. og Lehmann, D. R. (1994). Customer satisfaction, market share and profitability: Findings from Sweden. Journal of Marketing, 58(3), 5366.

Back, K. J. og Parks, S. C. (2003). A brand loyalty model involving cognitive, affective, and conative brand loyalty and customer satisfaction. Journal of Hospitality and Tourism Research, 27(4), 419-435.

Baumann, C., Burton, S. og Elliott, G. (2005). Determinants of customer loyalty and share of wallet in retail banking. Journal of Financial Service Marketing, 9(3), 231248.

Bendapudi, N. og Berry L. L. (1997). Customers' motivations for maintaining relationships with service providers. Journal of Retailing, 73(1), 15-37.

Boote, A. S. (1981). Reliability testing of psychographic scales. Journal of Advertising Research, 21(5), 53-60.

Bowen, J. T. og Chen, S.-L. (2001). The relationshipbetween customer loyalty and customer satisfaction. International Journal of Contemporary Hospitality Management, 13(5), 213-217.

Bowen, J. T. og Shoemaker, S. (1998). Loyalty: A strategic commitment. Cornell Hotel and Restaurant Administation Quarterly, 39(1), 12-25.

Caceres, R. C. og Paparoidamis, N. G. (2007). Service quality, relationship satisfaction, trust, commitment and business-to-business loyalty. European Journal of Marketig, 41(7/8), 836-867.

Chaudhuri, A. og Holbrook. M. B. (2001). The chain of effects from brand trust and brand affect to brand performance: The role of brand loyalty. Journal of Marketing, 65(2), 81-93.

Choi, D. H., Kim, C. M., Kim, S. I. og Kim S. H. (2006). Customer loyalty and disloyalty in internet retail stores: Its antecedents and its effect on customer price sensitivity. International Journal of Management, 23(4), 925-944.

Colgate, M. og Norris, M. (2001). Developing a comprehensive picture of service failure. International Journal of Service Industry Management, 12(3), 215-233.

Cugini, A., Carú, A. og Zerbini, F. (2010). Assessing and managing the cost of satisfaction in B2B service. Journal of Strategic Innovation and Sustainability, 6(4), 55-85. 
Cursai, C. F. og Kennedy, K. N. (2002). From prisoners to apostles: A typology of repeat buyers and loyal customers in service business. The Journal of Service Marketing, 16(4), 322-341.

Davis-Sramek, B., Droge, C., Mentzer, J. T. og Myers, M. B. (2009). Creating commitment and loyalty behavior among retailers: What are the roles of service quality and satisfaction? Journal of the Academy of Marketing Science, $37(4), 440-454$.

Dawes, J. G. (2008). Do data characteristics change according to the number of scale points used? An experiment using 5 point, 7 point and 10 point scales. International Journal of Market Research, 51(1), 61-77.

Day, G. S. (1969). A two-dimensional concept of brand loyalty. Journal of Advertising Research, 9(3), 29-35.

Dick, A. S. og Basu, K. (1994). Customer loyalty: Towards an integrated conceptual framework. Journal of the Academy of Marketing Science, 22(2), 99-113.

Espejel, J., Fandos, C. og Flavián, C (2008). Consumer satisfaction. A kay factor of consumer loyalty and buying intention of a PDO food product. British Fodd Journal, 110(9), 865-881.

Field, A. (2005). Discovering statistics using SPSS (2. útgáfa). London: SAGE Publication Ltd.

Field, A. (2009). Discovering statistics using SPSS (3. útgáfa). London: SAGE Publication Ltd.

Fisk, T. A., Brown, C. J., Cannizzaro, K. og Naftal, B. (1990). Creating patient satisfaction and loyalty. Journal of Health Care Marketing, 10(2), 5-15.

Foxall, G. R. (1987). Radical behaviourism and consumer research: Theoretical promise and empirical problems. International Journal of Research in Marketing, 4(2), 111-129.

Friðrik Eysteinsson og Pórhallur Guðlaugsson (2010). Bankahrunið. Traust til bankanna og tryggð við pá. Í Ingjaldur Hannibalsson (ritstjóri), Rannsóknir í félagsvísindum XI (bls. 52-61). Reykjavík: Félagsvísindastofnun Háskóla Íslands.

Gardener, E. og Trivedi, M. (1998). A communications gramework to evaluate sales promotion strategies. Journal of Advertising Research, 38(3), 67-71.

Gil-Saura, I., Frasquet-Deltoro, M. og Cervera-Taulet, A. (2009). The value of B2B relationships. Industrial Management \& Data Systems, 109(5), 593-609.

Gounaris, S. P. (2005). Trust and commitment influences on customer retention: Insights from business-to-business services. Journal of Business Research, 58(2), 126-140.

Gremler, D. D. og Brown, S. W. (1998). Service loyalty: Antecedents, components and outcomes. Í D. Grewal og C. Pechmann (ritstjórar), AMA Winter Educators' Conference: Marketing Theory and Applications (bls. 165-166). Chicago: American Marketing Association.

Hart, C. W. L., Heskett, J. L. og Sasser, W. E. (1990). The profitable art of service recovery. Harvard Business Review, 68(4), 148-156.

Helgesen, Ø. og Nesset, E. (2007). Images, satisfaction and antecedents: Drivers of student loyalty? A case study of a Norwegian university college. Corporate Reputation Review, 10(1), 38-59.

Helgesen, $\varnothing$. og Nesset, E. (2011). Does LibQUAL+ ${ }^{\mathrm{TM}}$ account for student loyalty to a university college library? Quality Assurance in Education, 19(4), 413-440. 
Hellier, P. K., Geursen, G. M., Carr, R. A. og Rickard, J. A. (2003). Customer repurchase intention. A general structural equation model. European Journal of Marketing, 37(11/12), 1762-1800.

Hirschman, A. O. (1970). Exit, voice and loyalty: Responses to decline in firms, organizations and states. Cambridge: Harvard University Press.

Homburg, C., Hoyer, W. D. og Koschate, N. (2005). Customers' reactions to price increases: Do customer satisfaction and perceived motive fairness matter? Journal of the Academy of Marketing Science, 33(1), 36-49.

Jones, T. O. og Sasser Jr., W. E. (1995). Why satisfied customers defect. Harvard Business Review, 73(6), 88-99.

Lam, S. Y., Shankar, V., Erramilli, M. K. og Murthy, B. (2004). Customer value, satisfaction, loyalty, and switching costs: An illustration from a business-tobusiness service context. Journal of th Academy of Marketing Science, 32(3), 293311.

Liao, K. H. (2012). Service quality, and cusomter satisfaction: Direct and indirect effects in a B2B customer loyalty framework. Journal of Global Business Management, 8(1), 86-93.

Martin, C. I. og Goodell, P. W. (1991). Historical, descriptive and strategic perspectives on the construct of product commitment. European Journal of Marketing, 25(1), 53-60.

Martín-Consuegra, D., Molina, A. og Esteban, Á. (2007). An integrated model of price, satisfaction and loyalty. An empirical analysis in the service sector. Journal of Product \& Brand Management, 16(7), 459-468.

Mattila, A. S. (2004). The impact og service failures on customer: The moderating role of affective commitment. International Journal of Service Management, 15(2), 134149.

McMullan, R. (2005). A multiple-item scale for measuring customer loyalty development. The Journal of Service Marketing, 19, 470-481.

Mellens, M., Dekimpe, M G. og Steenkamp, J.-B. E. M. (1996). A review of brandloyalty measures in marketing. Tijdschrift voor Economie en Management, 41(4), 507-533.

Mittal, B. og Lasser, W. M. (1998). Why do customer switch? The dynamics of satisfaction versus loyalty. Journal of Service Marketing, 12(3), 177-194.

Mittal, V., Ross, W. T. og Baldasare, P. M. (1998). The asymmetric impact og negative and positive attribute-level performance on overall satisfaction and repurchase intentions. Journal of Marketing, 62(1), 33-47.

Molinari, L. K., Abratt, R. og Dion, P. (2008). Satisfaction, quality and value and effects on repurchase and positive word-of-mouth behavioral intentions in a B2B service context. Journal of Service Marketing, 22(5), 363-373.

Odin, Y., Odin, N. og Valette-Florence, P. (2001). Conceptual and operational aspects of brand loyalty. An empirical investigation. Journal of Business Research, 53(2), 75-84.

Oliver, R. L. (1977). Effect of expectation and disconfirmation on postexposure product evaluations: An alternative interpretation. Journal of Applied Psychology, 62(4), 480-486.

Oliver, R. L. (1999). Whence consumer loyalty? Journal of Marketing, 63, 33-44. 
Olivia, T. A., Oliver, R. L. og MacMillan, I. C. (1992). A catastrophe model of developing service satisfaction strategies. Journal of Marketing, 56(3), 83-95.

Olsen, S. O., Wilcox, J. og Olsson, U. (2005). Consequences of ambivalence on satisfaction and loytalty. Psychology \& Marketing, 22(3), 247-269.

Patterson, P. G., Johnsons, L. W. og Spreng, R. A. (1997). Modeling the determinants of customer satisfaction for business-to-business professional service. Journal of the Academy of Marketing Science, 25(1), 4-17.

Pick, D. (2010). Never say never - Status Quo and research aenda for relationship termination in B2B markets. Journal of Business Marketing Management, 4(2), 91108.

Pritchard, M. P. og Howard, D. R. (1997=. The loyal traveler: Examining a typology of service patronage. Journal of Travel Research, 35(4), 2-10.

Ranaweera, C. og Prabhu, J. (2003). On the relative impotance of customer satisfaction and trust as determinants of customer retention and positive word of mouth. Journal of Targeting, Measurement and Analysis for Marketing, 12(1), 8290.

Rauyruen, P., Miller, K. E. og Groth, M. (2009). B2B services: Linking service loyalty and brand equity. Journal of Service Marketing, 23(3), 175-186.

Reichheld, F. F. (2003). The one number you need to grow. Harvard Business Review, 81(12), 46-54.

Reichheld, F F. og Sasser, W. E. (1990). Zero defections: Quality comes to services. Harvard Business Review, 68(5),105-111.

Reinartz, W. og Kumar, V. (2002). The mismanagement of customer loyalty. Harvard Business Review, 80(7), 86-94.

Rundle-Thiele, S. og Mackey, M. M. (2001). Assessing the performance of brand loyalty measures. The Journal of Service Marketing, 15, 529-545.

Russell-Bennett, R., McColl-Kennedy, J. R. og Coote, L. V. (2007). Involvement, satisfaction, and brand loyalty in a small business service setting. Journal of Business Research, 60(12), 1253-1260.

Rust, R. T. og Zahoric, A. J. (1993). Customer satisfaction, customer retention, and market share. Journal of Retailing, 69(2), 193-215.

Skogland, I. og Siguaw, J. A. (2004). Are you satisfied customers loyal? Cornell Hotel and Restaurant Administration Quarterly, 45, 221-234.

Söderlund, M. (1998). Customer satisfaction and its consequences on customer behavior revisited. The impact of different levels of satisfaction on word-ofmouth, feedback to the supplier and loyalty. International Journal of Service Industry Management, 9(2), 169-188.

Söderlund, M. (2006). Measuring customer loyalty with multi-item scales. A case for caution. Journal of Service Management, 17(1), 76-98.

Taylor, S. A. og Hunter, G. (2003). An exploratyory investigation into the antecedents of satisfaction, brand attitude, and loyalty within the (B2B) eCRM industry. Journal of Consumer Satisfaction, Dissatisfaction and Complaining behavior, 16, 1935.

Traylor, M. B. (1981). Product involvement and brand commitment. Journal of Advertising Research, 21(6), 51-56. 
Wangenheim, F. v. og Bayón, T. (2007). The chain from customer satisfaction via word-of-mouth referrals to new customer acquisition. Journal of the Academy of Marketing Science, 35(2), 233-249.

Westbrook, R. A. og Oliver, R. L. (1981). Developing better measures of consumer satisfaction. Advances in Consumer Research, 8(1), 94-99.

Woodruff, R. B. (1997). Customer value: The next source for competitive advantage. Journal of th Academy of Marketing Science, 25(2), 139-153.

Yi, Y. (1990). A critical review of customer satisfaction. Í V. Zeithaml (ritstjóri), Review of Marketing 1990 (bls. 68-123). Chicago: American Marketing Association.

Zahorik, A. J. og Rust, R. T. (1992). Modeling the impact of service quality on profitability: A review. Advances in Service Marketing and Management, 1, 247276.

Zeitmhaml, V. A., Berry, L. L. og Parasuraman, A. (1993). The nature and determinants of customer expectations of service. Journal of the Academy of Marketing Science, 21(1), 1-12.

Zeithaml, V. A., Berry, L. L. og Parasuraman, A. (1996). The behavioral consequences of service quality. Journal of Marketing, 60(2), 31-46.

Pórhallur Guðlaugsson (2010). Pjónustugæði sem vísir að tryggð. Í Ingjaldur Hannibalsson (ritstjóri), Rannsóknir í félagsvísindum XI (bls. 167-177). Reykjavík: Félagsvísindastofnun Háskóla Íslands. 